\title{
Religion and Philosophy: Brief Reflections
}

\author{
Villamil Rivas JA* \\ Universidad Nacional Autónoma de México, Mexico
}

*Corresponding author: Jorge Alberto Villamil Rivas, Profesor jubilado de la Universidad Nacional Autónoma de México, Hacienda de Santiago №67 Col Prados del Rosario Azcapotzalco

.Ciudad de México, Tel: 555394 79 32; Email: joalvillamil@yahoo.com.mx

\section{Conceptual Paper}

Volume 4 Issue 2

Received Date: May 31, 2021

Published Date: June 25, 2021

DOI: $10.23880 /$ phij-16000188

\section{Abstract}

In the following notes I will expose some motivated reflections in my classes on introductory topics to philosophy, in subjects that, under different names, I taught for more than half a century in the university baccalaureate of UNAM.

In particular, I will refer to the interest of my young students in matters related to religious thought and science, notably those that address the study of social problems.

Keywords: Religion; Social problems; Philosophy

\section{Religion and Philosophy}

In the classroom, questions relating religion and magic to philosophical problems have always been an important stimulus and a basis for attracting interest and provoking debate. Religion is a psychological, social, historical, political phenomenon... it is disturbing and disconcerting and the relationship it has with philosophy is so intimate that it leads us to treat specific problems with not only different approaches but on many occasions opposite and in frank confrontation. As examples whose only mention involves a range of connections, interactions and debates we can mention among many others: the big-bang, the origin of man and woman, thought, evil... etc. that refer us to the more general reflection on science and religion.

In the XXI century, faced with the impressive development of the natural sciences and the investigation of the universe and its results in technological progress, the evident revitalization of religious searches and corresponding ritual practices throughout the world continues to surprise.

This contemporary religiosity is characterized, among other qualities, by the attempts of believers to find, renew or rethink the absolute foundations of traditional values.
They are attempts of diverse origins that are even combined with their opposites: these, for their part, promote the relativization of current values (which is not a loss) and also with a certain lack and confusion of the meaning of life.

For all this, it seems to me, the study and research of the religious phenomenon is imperative: what are they and why are religions maintained and renewed?

I believe that similar problems cannot be satisfactorily addressed from a single perspective, be it philosophical, sociological, psychological, historical, anthropological, epistemological, or ethical... The abundant subject matter demands globalizing visions, although to construct solid theoretical proposals it is necessary to start from some Preferential disciplinary approach. That is to say that the study and analysis is carried out from some scientific discipline but that it does not dissociate itself from its connections with history, philosophy, psychology or politics, for example.

\section{Comprehensive Vision}

The study of any problem with religious implications requires for its analysis, a thorough understanding of the 


\section{Philosophy International Journal}

integrative activity. It is important to be clear that religion is precisely a historical phenomenon, or political, psychological, etc... but that it inevitably interrelates different research spaces. The great philosophical / political ideologies that offer substitute avenues for a comprehensive understanding of the world and of life thus take on the greatest importance.

Values, whose indubitable character no longer comes from a perfect divinity, as in the old religious doctrines, do derive from great theoretical-ideological constructions that offered, until very recently, alternative ways to faith, suddenly, too, have shown a A crisis so deep that there are those who have declared that with the turn of the century (and the millennium) we have reached the end of ideologies and even the end of history.

The truth is that the natural and social sciences are splendid with their proven truths, their efficiency, and their ability to penetrate the secrets of nature and society, they also provide the necessary modesty that places us in the universe without dogmatic pretense of uniqueness and pride than in other times; it made us smug and led us to pretend that we were the "kings of creation."

However, soon, science, scientific truth, has shown us that, despite its powerful tools, it cannot offer hope, refuge, or comfort, as "truths of faith" do. Science is cold and out of supply. of illusions. Neither ideologies in crisis nor implacable science have that appeal offered by any of the religious beliefs that even offer a "salvation", whatever that may be. They promise a destiny of happiness beyond death including, in addition, the punishment for the bad or sinners and the prize of heavenly glory for the good.

Science only offers - if it offers anything - a path of analysis and demonstration, trial and error... And, furthermore, it requires a lot of effort. But we certainly cannot conceive of a better path

Until very few centuries ago, in the West and minevitably interrelates different research spaces. The great philosophical / political ideologies that offer substitute avenues for a comprehensive understanding of the world and of life thus take on the greatest importance.

Values, whose indubitable character no longer comes from a perfect divinity, as in the old religious doctrines, do derive from great theoretical-ideological constructions that offered, until very recently, alternative ways to faith, suddenly, too, have shown a A crisis so deep that there are those who have declared that with the turn of the century (and the millennium) we have reached the end of ideologies and even the end of history.
The truth is that the natural and social sciences are splendid with their proven truths, their efficiency, and their ability to penetrate the secrets of nature and society, they also provide the necessary modesty that places us in the universe without dogmatic pretense of uniqueness and pride than in other times; it made us smug and led us to pretend that we were the "kings of creation".

However, soon, science, scientific truth, has shown us that, despite its powerful tools, it cannot offer hope, refuge, or comfort, as "truths of faith" do. Science is cold and out of supply. of illusions. Neither ideologies in crisis nor implacable science have that appeal offered by any of the religious beliefs that even offer a "salvation", whatever that may be. They promise a destiny of happiness beyond death including, in addition, the punishment for the bad or sinners and the prize of heavenly glory for the good.

Science only offers - if it offers anything - a path of analysis and demonstration, trial and error... And, furthermore, it requires a lot of effort. But we certainly cannot conceive of a better path

Until very few centuries ago, in the West and Middle East the great religions seemed doomed to decline and even extinction. The constant advance of the natural sciences that collide with the dogmas emanating from the beliefs, causes anger among the diffusers of what each congregation considers the true truth and generates warlike reactions that have lasted centuries and are periodically renewed.

The disagreements and persecutions against sages and free thinkers have been constant in history. The infamies committed against medieval and Renaissance scientists who did not discipline themselves and raised new discoveries and explanations about the world, the human being and society are known. And they also offered evidence.

Liberal thinkers in both science and politics instead of giving in to intransigence, they bravely stood and developed. Liberal thought grew, dispersed, and let its branches spread. With support from the works of the Enlightenment and the Renaissance, voices were heard against the imposition of dogmas. And in response to intransigence, religion was sentenced by $19^{\text {th }}$ century materialism; unmasked by Feuerbach as alienating, described by Marx and Marxism as the opium of the peoples while Nietzsche in the passage from the $19^{\text {th }}$ to the $20^{\text {th }}$ century decreed the death of God.

But, finally in the midst of the world crises of the current centuries, the religious search, in various tendencies, has regained strength with the deepening of fundamentalisms as radical as those that are manifested, for example, in currents 


\section{Philosophy International Journal}

of extremist Islam as well as in the proliferation of new groups and churches, (called sects) that adduce attractive formulas of salvation and support the relative strengthening of the ancestral churches.

The oldest religions that survive in the new millennium of what is still called the Christian era, although they do not show an obvious danger of extinction, suffer strong shakes that on the one hand tear them apart and on the other throw their representative churches down different paths, sometimes opposite each other. We often find them navigating towards, a modernization (or updating) that, in many cases, makes them more tolerant and liberal or, on the contrary, we see them involved in sectarian, offensive and defensive movements promoting radical and violent positions.

Between both poles a wide range unfolds with a great variety of shades. All acting simultaneously. Churches such as the Catholic, for example, debate within themselves in opposite positions that on occasions like those that occurred in the second half of the last century, when they aligned their priesthood in a revolutionary and radical perspective inscribed in the class struggle theses they promoted with some success, until very recently, various militant tendencies of the currents of materialist Marxism and liberation theology.

And at the same time, on the opposite side, we find conservative priests upholding and promoting anachronistic positions of visceral and indiscriminate condemnation of popular movements and even applauding repressive measures promoted by wealthy social sectors.

\section{Religion Intervenes}

But religions move and express themselves in multiple manifestations. Let's see some examples that invite us to philosophize:

In certain controversial spaces of social life, such as that of sexual diversity and its multiple implications, Catholicism - and by extension a good number of other Christianisms - as well as Islam - shows sharp and constant contradictions.

Faced with each specific problem that we wish to consider, we find a range of positions and counter-positions that not only differ but even express their differences with violence. They highlight, for example, the difficulties that ministers of worship and believers face around issues such as divorce, birth control, child pornography, celibacy, the social and doctrinal position of women, abortion, homophobia, virginity, bisexuality, trans-gender changes and cloning and biotechnology applied to human beings, among other thorny issues. And while all this is being debated, the atmosphere is heated by nuns who want to officiate mass and priests who marry, scandalizing the old conservatives.

\section{Criminals: The Blackest}

In other settings in various parts of the world criminal acts are committed for religious reasons. Some of them lead us to verify that the darkness of fanaticism, intolerance and the death sentence for reasons of belief and worship are not something of an ominous past. They are ruthless crimes that, regardless of their modalities, persist and continue to cause harm to the population. Shocking crimes abound that are part of our circumstances but that only mediately become linked to our daily reality and do not stop hitting the conscience, showing always threatening abysses.

Cases taken at random illustrate and draw us dark passages of a very steep abyss of the blackest of religion that we have barely peered into. I mention them below

Shortly before the end of the last century we recorded the iconic case of a collective crime carried out by a mafia and a religious sect at the same time. It is about the induced suicide and collective murder of the members of the community called El Templo del Pueblo. This crime occurred in the seventies, in the South American lands of Guyana. The group was led by an "enlightened" named Jim Jones who ordered the death of almost a thousand followers of him who were supposed to build a kind of paradise.

Another case of a murderous sect led by a preacher named David Koresh, was registered in Yaco, USA; towards the end of the millennium the collective death of the socalled Davidians was induced with blind fanaticism, by the preacher who said Jesus Christ was revived and thus led his parishioners to death.

\section{Devil and Satanism}

We read cases like these in highly discussed and debatable pages that relate gruesome facts of the blackest of the religious phenomenon. And they refer us to the supposed presence and force of what we know as EVIL. All religions have postulated and still postulate one or more evil beings that are characterized by their absolute opposition to the good deities. His supposed intervention in human affairs is inescapable.

The devil and Satanism are undoubtedly invented entities, out of fear and ignorance, ancestral beliefs that have not disappeared in the popular imagination. All kinds of evil behavior are recorded around its supposed existence and presence, accompanied by myths, legends and, surprisingly, 


\section{Philosophy International Journal}

by multiple works of art of the highest quality.

In Mexico near the end of the twentieth century we record multiple episodes such as that of the so-called fanatical delinquent Narcosatanicos who committed various human sacrifices supposedly in honor of malevolent deities of the Palo Mayombé, a variant rite of Voodoo. Discarded bodies with the marrow and the heart removed were part of that horror.

\section{Politics and weapons}

From another perspective, it is important to cite the armed conflicts that do not cease in the Middle East, since they are battles that with Pretexts and religious wrapping have involved several countries of the world in endless war episodes, notably between Jews and Palestinians. The rulers of the U.S. followers of the Christian God are confessed, according to the expression of presidents like George Bush. And in contrast to the words of Muslim leader Sadamm Hussein who called his fighters chosen by Allah to wage holy war against the West, The barbarism of technological warfare is frequently broadcast live around the world on television and currently on modern networks. The destruction of real cities with the dead of flesh and blood has become a terrifying spectacle, in which the different gods of Christianity, Islam and Judaism are involved.

All this is just an elementary sample of the danger more complex and widespread than we can imagine; its frequency and diversity horrifies us and turns on the red light of a preventive alarm. The religious envelope is a key point that interests and determines any analysis. From the outset it needs to be investigated and above all understood. Of course, it demands to be studied by Philosophy.

\section{Luminous notes}

But there are also, shining, the positive notes on the other side of the mirror. Other extremely important realities can be considered as the noble and beautiful part of the existence of cults and religions.

The human sensitivity that devotion produces in the faithful constitutes an invaluable treasure of humanity that must be fully preserved. Not everything is tragedy, alienation, intolerance and crime in the game of beliefs; the countless jewels and monuments inherited by the religions to the different peoples are registered among the most remarkable and stimulating human creations.

Among the thousands of examples that we could cite on this bright side, we have, in addition to the production of all kinds of works of art and the formation of beautiful traditions, the constant call from the various creeds to love others and to adore a God who, according to the rite, forgives the repentant and who supposedly loves everyone equally. Acts to invoke world peace, both the Catholic Pope and the Dalai Lama, are always welcomed by all men of peace in the world.

Other experiences, which are also positive signs of worship, and of essential importance in human existence, are the feelings of protection, comfort and hope that beliefs produce in the faithful, as well as those that produce feelings of identity and belonging. to a community. And to humanity itself.

Thus, when we speak of the religious phenomenon, what amazes and produces culturally positive feelings is combined with a set of tortuous and macabre facts that inevitably form a substantial part of the complex reality. An understanding challenge for philosophy investigating about religion pushes us to consider the dark grounds of crime and so-called sin, which, in short, configures a reality that is extremely difficult to clarify, However, the worst we can do is evade the challenge to pretend calamities don't exist.

A popular advice that expresses the very generalized attitude that seeks to disguise or conceal the impotence of the fearful people who lack reasons and arguments, is the one that maintains that "religion and politics are not discussed". The implicit suggestion of this approach is that of ignoring doubts, difficulties and problems that, however, remain there. What this saying really proposes is closing your eyes to deny political or religious reality. On the contrary, I consider that what is necessary is to debate (not to fight).

\section{Philosophy: Open Road}

Religion has been and is a subject always open to new unknowns. In the first place in the field of philosophy. It is not limited to a single elaboration, since it includes from the conceptions of the world, the human being and life, as well as social relations and politics to the most intimate and personal fibers of the believer. It takes care of the cults while offering formulas for a behavior pleasing to the divinities. It combines very deep human facts, desires, fantasies and feelings. Multiple and diverse scientific disciplines and the greatest thinkers have dealt with religion, its issues and problems. Each concept is a polysemic issue that summons all the sciences. The Light of philosophy is in the writings of the greatest geniuses of all time: from there they shine: Hesiod, Xenophanes, Epicurus, Plato and Aristotle, to Hegel, Marx, Nieztche, Freud and Russell passing through the entire history of thought: Descartes, Hume, Hobbes, Voltaire, D'Holbach, Diderot, Spinoza, Kant, Feuerbach, Frazer, Levi Strauss, Eliade, Jaeger, Cassirer, Fromm and several important 
etceteras.

We cannot say, however, that the obvious difficulties in understanding the religious phenomenon have dissipated. Philosophy still has a lot to explore, analyze, propose. It's open road. 